\title{
ANALISIS KOMPOSISI ASAM LEMAK PADA MINYAK KELAPA FERMENTASI DAN MINYAK KELAPA TRADISIONAL
}

\author{
Fatma Al Hamid', J. Leiwakabessy², A. Bandjar ${ }^{3}$ \\ ${ }^{1}$ Program Studi Pendidikan Kimia, Jurusan MIPA FKIP Unpatti \\ 2Jurusan IImu Kelautan Fakultas Perikanan Unpatti \\ ${ }^{3}$ Jurusan Kimia Fakultas Matematika dan IImu Pengetahuan Alam Unpatti \\ E-mail: fatmahamid625@yahoo.com
}

Diterima 15 Maret 2019/Disetujui 20 April 2019

\begin{abstract}
Analysis of fatty acid in ferment coconut oil and traditional coconut oil has been concluded by GC-MS. The result of analysis in ferment coconut oil yiels four kinds of fatty acid that are (1). Laurate acid (methyl dodekanoat) 39,13\%, (2). Myristate acid (methyl tetradekanoat) 13,78\%, (3). Palmitate acid (methyl heksadekanoat) 6,60\%, and (4). Oleate acid (Methyl 9-oktadekanoat) 4,81\%. While traditional coconut oil yiels five kinds of fatty acid, that are (1). Laurate acid (methyl dodekanoat) 44,83\%, (2). Myristate acid (methyl tetradekanoat) 22,83, (3). Palmitate acid (methyl heksadekanoat) 12,82\%, (4). Oleate acid (Methyl 9-oktadekanoat) 11,16\%, and (5) Stearate acid (Methyl oktadekanoat) 3,90\%. Stearate acid is none in ferment coconut oil because it lost used by khamir. Traditional coconut oil is better than ferment coconut oil in number and kind of fatty acid. But from the physic character like number of oil, time cook, and face, ferment coconut oil is better. Method made is influence to compound of fatty acid. In other research, it's important to find the optimal condition procces for khamir fermentation. People may eat traditional coconut oil cos it have some fatty acid that important for human body.
\end{abstract}

Key wodrs: Fatty acid, transesterification, khamir, fermentation.

\begin{abstract}
ABSTRAK
Telah dilakukan analisis asam lemak dalam minyak kelapa fermentasi dan minyak kelapa tradisional dengan GC-MS. Analisis asam lemak dalam minyak kelapa fermentasi diperoleh empat jenis asam lemak yaitu (1). Asam laurat (Metil dodekanoat) 39,13\%, (2). Asam miristat (Metil tetradekanoat) 13,78\%, (3). Asam palmitat (Metil heksadekanoat) $6,60 \%$, dan (4). Asam oleat (Metil 9-oktadekanoat) 4,81\%. Sedangkan dalam minyak kelapa tradisional diperoleh 5 jenis asam lemak yaitu (1). Asam laurat (Metil dodekanoat) 44,83\%, (2). Asam miristat (Metil tetradekanoat) 22,82\%, (3). Asam palmitat (Metil heksadekanoat) 12,82\%, (4). Asam oleat (Metil 9 oktadekanoat) $11,16 \%$, dan (5). Asam stearat (Metil oktadekanoat) 3,90\%. Asam stearat tidak ada dalam minyak kelapa fermentasi karena telah habis dikonsumsi khamir. Dari segi jumlah dan jenis asam lemak, minyak kelapa tradisional lebih banyak namun dari segi fisik dalam hal jumlah minyak, waktu pemanasan dan tampilan, minyak kelapa fermentasi lebih baik. Proses pembuatan mempengaruhi komposisi asam lemak. Dalam penelitian selanjutnya perlu diberikan nutrisi tambahan buat khamir agar asam lemak tidak dikonsumsi. Perlu dilakukan penelitian untuk mencari kondisi optimal proses fermentasi khamir. Masyarakat boleh mengkonsumsi minyak kelapa fermentasi karena mengandung asam lemak yang penting bagi tubuh.
\end{abstract}

Kata kunci: Asam lemak, transesterifikasi, khamir, fermentasi

\section{PENDAHULUAN}

Minyak dan lemak pada hakikatnya adalah sama yakni suatu trigliserida, bedanya adalah minyak berwujud cair pada suhu ruang sedangkan lemak berwujud padat pada suhu ruang (Afandi, 1982). Kandungan lemak dan komposisi asam lemak dalam bahan pangan menjadi perhatian utama 
bagi konsumen maupun saintis, karena mengkonsumsi lemak erat kaitannya dengan masalah gizi dan kesehatan. Perhatian masyarakat terhadap lemak pangan semakin menjadi besar terutama setelah diketahui bahwa mengkonsumsi lemak berlebihan akan mempengaruhi kesehatan, tidak saja terhadap meningkatnya penyakit jantung koroner, tetapi akhir-akhir ini diinformasikan juga terhadap penyakit kanker, diabetes dan tekanan darah tinggi (Almatsier, 2002).

Komposisi asam lemak dalam minyak kelapa dipengaruhi oleh beberapa faktor yaitu: jenis, umur dan habitat dari buah kelapa yang dipakai untuk membuat minyak. Selain itu tinggi rendahnya asam lemak dalam minyak juga dapat disebabkan oleh bagaimana proses pengolahan dan penyimpanan dari minyak itu sendiri. Proses pengolahan yang berbeda-beda dapat menyebabkan komposisi asam lemak yang berbeda pula akibat peluang rusaknya asam lemak (mungkin akibat panas, adanya mikroorganisme, dan lain-lain).

Pembuatan minyak kelapa dapat dilakukan dengan dua cara, yaitu: cara kering dan cara basah. Cara kering dibuat melalui pembuatan kopra, selanjutnya dipres atau diekstraksi sehingga minyak keluar. Sedangkan pembuatan minyak secara basah adalah dengan melalui pembuatan santan dari daging buah kelapa segar (tanpa pengeringan), kemudian memecah emulsi antara minyak dan air untuk mendapatkan minyaknya. Cara basah tradisional dilakukan dengan memanaskan krim santai hingga seluruh airnya menguap, protein kelapa menggumpal menjadi glendo (tahi minyak) dan diperoleh minyak kelapa (Sukmadi, 1981).

Cara lain untuk mendapatkan minyak kelapa secara basah adalah cara fermentasi. Pembuatan minyak kelapa secara fermentasi dilakukan dengan menggunakan mikroorganisme sebagai inokulum yaitu spesies khamir atau bakteri yang mempunyai daya fermentasi untuk mempercepat pemecahan emulsi krim santan sehingga memisah menjadi tiga fase yaitu: minyak, protein dan air. Sebagai inokulum dapat digunakan ragi roti (gist). Fermentasi santan dengan inokulum dapat menghasilkan pemisahan minyak yang sangt baik (Sukmadi, 1987).

Kedua metode pembuatan minyak kelapa secara tradisional berpeluang untuk mengurangi atau merusak salah satu komponen dalam minyak yang sangat dibutuhkan manusia yaitu asam lemak tak jenuh. Asam lemak tak jenuh terdiri atas asam lemak tak jenuh tunggal (MUFA = monounsatured fatty acid) yang memiliki satu ikatan rangkap dua dan asam lemak tak jenuh jamak (PUFA = Poliunsatured fatty acid) yang memiliki lebih dari dua ikatan rangkap dua. Ikatan rangkap mengandung satu ikatan $\sigma$ yang kuat dan satu ikatan $\pi$ yang lemah. Ikatan $\pi$ dikatakan lemah karena elektron pada ikatan ini letaknya lebih tersingkap ke luar dan jauh dari inti sehingga lebih mudah dipengaruhi efek dari luar seperti serangan oleh atom atau molekul maupun pemanasan, dari pada elektron dari ikatan $\sigma$ (Fessenden, 1987).

Menurut Siburia (2005) MUFA dan PUFA dapat mengurangi kadar kolesterol dan trigliserida darah. PUFA dapat menyebabkan darah menjadi kurang lengket dan kecil kemungkinannya untuk menjadi lengket. PUFA bahkan mampu memperbaiki dinding (pembuluh darah) arteri yang rusak oleh karena kelebihan konsumsi lemak jenuh (penyakit arteriosklerosis) (Winarno, 1999). Asam lemak sangat erat kaitannya dengan masalah gizi dan kesehatan sehingga perlu dilakukan penelitian untuk mengetahui komposisi asam lemak pada minyak kelapa hasil fermentasi dengan minyak kelapa tradisional.

\section{METODE PENELITIAN}

\section{Alat}

Alat yang dipakai dalam penelitian ini adalah: gelas kimia (Pyrex), erlenmeyer (Pyrex), labu fermentasi (Pyrex), termometer (Pyrex), batang pengaduk (Pyrex), eksikator, gelas ukur (Pyrex), 
pipet tetes (Pyrex), alat penghisap (Pyrex), labu alas bulat (Pyrex), penangas air, autklaf (All Americana), oven (Cimarec), seperangkat alat GC-MS (Simadzu), kertas saring whatman nomor 1.

\section{Bahan}

Bahan yang dipakai dalam penelitian ini adalah: ragi roti (gist) sebanyak $5 \mathrm{gr}$, buah kelapa tua sebanyak 8 buah, metanol absolut p.a, BF 3 15\% p.a, n-Heksana p.a.

\section{Prosedur Kerja}

\section{A. Pembuatan minyak kelapa fermentasi}

1. Prosedur pembuatan santan

Ekstraksi daging buah kelapa segar dicampur aguades dengan perbandingan $1: 1,5$ menghasilkan santan yang setelah didiamkan dalam corong pisah sampai terjadi pemisahan diperoleh dua lapisan yaitu lapisan atas (krim santan) dan lapisan bawah (skim santan).

\section{Prosedur pembuatan larutan inokulum}

Cara pembuatan larutan inokulum adalah sebagai berikut: masukkan skim santan ditambah air kelapa dengan perbandingan $9: 1(\mathrm{v} / \mathrm{v})$ ke dalam labu erlenmeyer sebanyak $500 \mathrm{ml}$. Masukkan campuran tersebut ke dalam autoklaf pada suhu $121^{\circ} \mathrm{C}$, tekanan $1 \mathrm{~atm}$, selama \pm 15 menit. Setelah didinginkan kemudian dinokulasi dengan ragi roti (Gist) sebanyak $1 \mathrm{gr}$ untuk $500 \mathrm{ml}$ larutan, kemudian diinkubasi pada suhu kamar selama 24 jam.

\section{Prosedur inokulasi substrat}

Masukkan krim santan dan larutan inokulum ke dalam labu fermentasi dengan perbandingan 5 : $1 \mathrm{v} / \mathrm{v}(2100 \mathrm{ml}$ krim santan dan $500 \mathrm{ml}$ larutan inokulum). Labu ditutup rapat, diaduk/dikocok sebentar supaya air bibit tercampur dalam substrat kemudian didiamkan (diinkubasi) pada suhu kamar selama 48 jam.

\section{Prosedur pemisahan minyak kelapa}

Setelah proses fermentasi, terjadi pemisahan menjadi dua lapisan. Lapisan atas merupakan campuran minyak dan protein sedangkan lapisan bawah merupakan air keseluruhan. Lapisan bawah (air) dikeluarkan dari labu dan sisanya (minyak dan protein) dimasukkan ke dalam labu yang bersih selanjutnya dipanaskan pada suhu $80-100^{\circ} \mathrm{C}$ selama 5 - 10 menit tergantung isi labu sambil diadukaduk sampai protein mengendap. Setelah itu didinginkan kemudian difiltrasi untuk memisahkan bagian minyak lebih sempurna kemudian diukur jumlah minyak yang dihasilkan (Sukmadi, 1987).

\section{B. Pembuatan minyak kelapa tradisional}

Cara pembuatan santan sama dengan minyak kelapa fermentasi. Setelah santan siap langsung dipanaskan sampai seluruh airnya menguap, protein terdenaturasi menjadi glendo dan difiltrasi untuk mendapatkan minyak.

\section{Prosedur uji kualitas minyak kelapa}

Minyak hasil fermentasi dihilangkan kadar airnya lalu dilakukan transesterifikasi, kemudian hasilnya diidentifikasi dengan GC-MS. Hal yang sama juga dilakukan untuk minyak kelapa tradisional.

1. Penghilangan kadar air

Tambahkan natrium sulfat anhidrous ke dalam minyak kemudian bahan dimasukkan ke dalam eksikator, disaring lalu ditimbang. Ulangi sampai didapat berat konstan.

2. Transesterifikasi (uji komposisi asam lemak)

Ke dalam labu alas bulat $50 \mathrm{ml}$ ditambahkan larutan $1 \mathrm{ml}$ BF3 15\% dalam metanol pada kurang dari satu gram minyak kemudian dipanaskan di atas penangas air selama 30 menit. Setelah dingin ditambahkan $9 \mathrm{ml}$ n-Heksana dan $8 \mathrm{ml}$ aquades. Selanjutnya dikocok dan didiamkan sampai 
terbentuk dua lapisan. Lapisan bawah yang mengandung gliserol dipisahkan. Sedangkan lapisan atas (organik) yang mengandung metil ester asam lemak dikeringkan dengan natrium sulfat anhidrous kemudian disaring. Pelarutnya diuapkan, hasilnya campuran metil ester yang telah siap diidentifikasi dengan GC-MS.

\section{HASIL PENELITIAN}

\section{Pembuatan Santan dan Proses Fermentasi}

Hasil isolasi santan yang diekstraksi dari $2,83 \mathrm{~kg}$ daging buah kelapa segar yang dicampur aquades dengan perbandingan $1: 1,5(\mathrm{~g} / \mathrm{ml})$, diperoleh santan sebanyak 3,5 liter.

Hasil inokulasi skim santan dengan larutan inokulum selama 48 jam, maka terjadi proses fermentasi yang memecah emulsi krim santan sehingga memisah menjadi fase air, protein, dan minyak. Menurut Sukmadi (1987) peristiwa pemecahan emulsi krim santan secara fermentasi dapat diterangkan sebagai berikut. Mula-mula gula yang terdapat pada krim santan dan bertindak sebagai emulsifier difermentasi oleh khamir menjadi asam-asam organik. Pemecahan gula di atas dilakukan melalui jalur glikolisis atau Embden Mayernof Pathway. Setelah gula hilang dan terbentuk asam, ionion $\mathrm{H}^{+}$sebagai hasil penguraian asam-asam tersebut akan mendenaturasi protein yang juga sebagai emulsifier melalui penetralan gugus karboksilnya. Akibatnya protein menjadi tidak stabil dan mudah terlepas dan selanjutnya mengendap. Jika lapisan emulsifier sudah tidak ada seluruhnya, maka butiran minyak akan mudah bersatu untuk membentuk lapisan minyak tersendiri. Pembentukan lapisan minyak ini juga dibantu dengan pemanasan agar protein yang diperkirakan masih terdapat pada lapisan minyak tersenut dapat tergumpalkan dan akhirnya mengendap ke bawah.

Sementara itu pada pembuatan minyak kelapa secara tradisional mula-mula santannya dimasak sampai seluruh airnya menguap. Protein kelapa terdenaturasi dan menggumpal menjadi tahi minyak (glendo), selanjutnya difiltrasi untuk mendapatkan minyaknya.

Tabel 1. Hasil pengamatan proses pembuatan minyak kelapa fermentasi dan tradisional

\begin{tabular}{|l|l|l|}
\hline Parameter & $\begin{array}{l}\text { Minyak } \\
\text { Fermentasi }\end{array}$ & $\begin{array}{l}\text { Minyak } \\
\text { Tradisional }\end{array}$ \\
\hline Jumlah santan $(\mathrm{ml})$ & 500 & 500 \\
Jumlah minyak $(\mathrm{ml})$ & 125 & 112 \\
Waktu masak $(\mathrm{mnt})$ & \pm 6 & \pm 25 \\
Warna minyak & Bening & Lembayung \\
\hline
\end{tabular}

Dari Tabel 1 dapat dilihat bahwa jumlah minyak yang dibuat secara fermentasi lebih unggul dibandingkan minyak yang dibuat dengan cara tradisional dalam hal jumlah minyak dan lamanya pemanasan, yaitu untuk minyak fermentasi dari $500 \mathrm{ml}$ santan diperoleh minyak $125 \mathrm{ml}$ sedangkan minyak tradisional dari $500 \mathrm{ml}$ santan didapat minyak $112 \mathrm{ml}$. Waktu pemanasan untuk minyak kelapa fermentasi lebih sedikit dari minyak kelapa tradisional, yaitu 6 menit untuk minyak kelapa fermentasi dan 25 menit untuk minyak kelapa tradisional. Hal ini disebabkan karena pada minyak kelapa fermentasi, setelah proses fermentasi selesai sudah terbentuk minyak seperti yang telah dijelaskan sebelumnya. Sehingga pemanasan disini bertujuan untuk menggumpalkan protein yang diperkirakan masih terdapat pada lapisan minyak agar mengendap. Sedangkan pemanasan pada minyak kelapa tradisional berfungsi menguapkan air secara keseluruhan dan mendenaturasi protein.

\section{Hasil Transesterifikasi dengan GC-MS}

1. Minyak Kelapa Fermentasi 
Hasil analisis dengan menggunakan GC terdapat 11 puncak kromatogram yang menunjukkan bahwa terdapat 11 senyawa dan setelah dilakukan pendekatan pustaka terhadapa spektrum massa dari masing-masing puncak, didapat 6 jenis senyawa yang teridentifikasi, yaitu dua senyawa ..., metil laurat, metil miristat, metil palmitat, dan metil oleat.

Puncak kromatogram dengan waktu retensi 16,560 menit dengan kemurnian 9,20\% bukan merupakan senyawa metil ester.

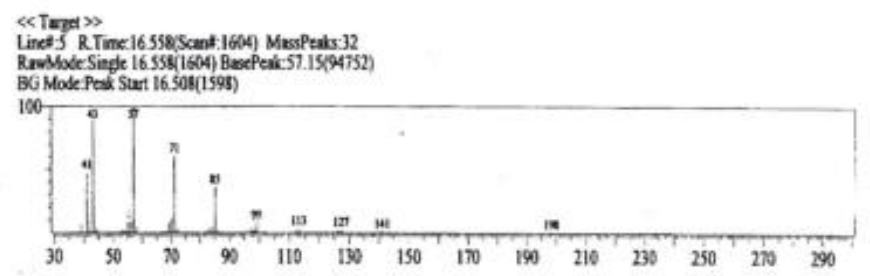

Gambar 1. Spektrum masa senyawa dengan waktu retensi 16,560 menit

Bila dilihat dari limpahan-limpahan yang dihasilkan oleh spektrum massanya, senyawa ini bukan merupakan senyawa metil ester. Hal ini ditandai dengan tidak munculnya pemecahan $\alpha$ maupun $\beta$ yang ditandai dengan munculnya limpahan pada $\mathrm{m} / \mathrm{z} 59$ dan 31 atau $\mathrm{m} / \mathrm{z} 74$. Puncak dasar muncul pada $\mathrm{m} / \mathrm{z} 57$ dan disertai dengan limpahan pada m/z 141, 127, 113, 99,85 dan 71 yang merupakan limpahan dari ion $\mathrm{C}_{n} \mathrm{H}_{2 n+1}{ }^{+}$yang merupakan ciri khas dari alkana.

Puncak kromatogram dengan waktu retensi 17,975 menit dengan kemurnian 5,82 \% bukan merupakan senyawa metil ester.

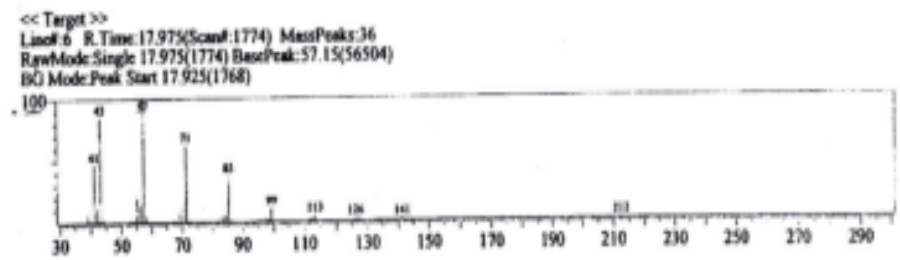

Gambar 2. Spektrum masa senyawa dengan waktu retensi 17,975 menit

Bila dilihat dari limpahan-limpahan yang dihasilkan oleh spektrum massanya, senyawa tersebut bukan merupakan senyawa metil ester. Hal ini terbukti dengan tidak adanya pemecahan a maupun $\beta$ yang ditandai dengan munculnya limpahan pada $\mathrm{m} / \mathrm{z} 59$ dan 31 atau $\mathrm{m} / \mathrm{z} 74$. Puncak dasar muncul pada $\mathrm{m} / \mathrm{z}$ 57. Ini merupakan ciri khas dari senyawa alkana.

Puncak kromatogram dengan waktu retensi 18,335 menit dengan kemurnian 39,3 \% adalah metil laurat.

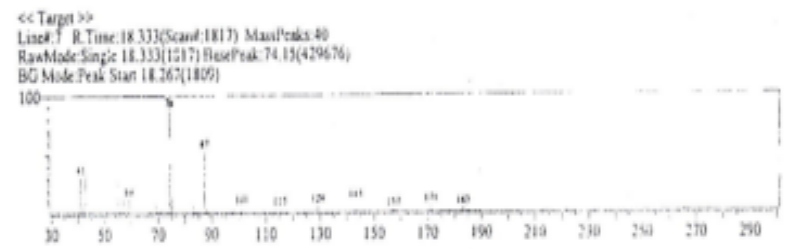

Gambar 3. Spektrum massa senyawa dengan waktu retensi 18,335 menit 
Puncak ion molekul pada $\mathrm{m} / \mathrm{z}=183$. Hal ini disebabkan karena lepasnya gugus metoksi (M-31). Gugus ini mungkin terlepas pada waktu destilasi untuk menghilangkan pelarut. Puncak dasar muncul pada $\mathrm{m} / \mathrm{z} 74$ yang berasal dari $\mathrm{C}_{3} \mathrm{H}_{6} \mathrm{O}_{2}{ }^{+}$, yang terbentuk karena pemecahan $\beta$ dari ion molekul melalui penataan ulang Mc. Lafferty (Creswel et al, 1982). Pecahan $\mathrm{m} / \mathrm{z}=171,157,143,129,115,101$ dan 87 merupakan hasil pemecahan deret ion dengan rumus $\mathrm{C}_{n} \mathrm{H}_{2 n+1}{ }^{+}$, yaitu untuk $\mathrm{m} / \mathrm{z} 171$ berasal dari pelepasan gugus propil dari puncak ion molekul standar $\mathrm{m} / \mathrm{z} 214$. Sedangkan yang lainnya berasal dari pelepasan gugus $\mathrm{CH}_{2}$. dari pola fragmentasinya dapat diketahui bahwa senyawa tersebut adalah metil laurat.

Puncak kromatogram dengan waktu retensi 20,859 menit dengan kemurnian 13,78\% merupakan senyawa metil miristat.

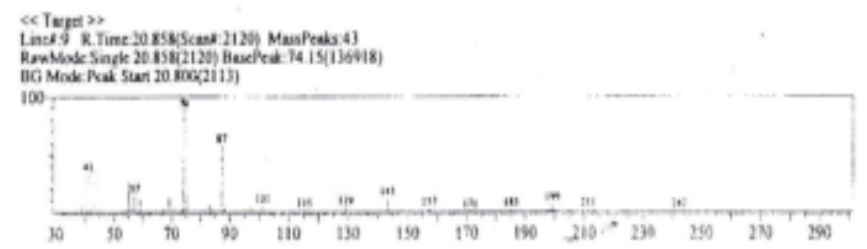

Gambar 4. Spektrum massa senyawa dengan waktu tR 20,859 menit

Gambar di atas menunjukkan bahwa ion molekul pada $\mathrm{m} / \mathrm{z}=242$. Puncak dasar muncul pada $\mathrm{m} / \mathrm{z}=74$ berasal dari $\mathrm{C}_{3} \mathrm{H}_{6} \mathrm{O}_{2}{ }^{+}$yang terbentuk karena pemecahan $\beta$ melalui penataan ulang Mc. Lafferty. Pecahan dengan $\mathrm{m} / \mathrm{z}=211(\mathrm{M}-31)$ berasal dari $\mathrm{C}_{14} \mathrm{H}_{27} \mathrm{O}^{+}$yang dihasilkan oleh lepasnya gugus metoksi dari puncak ion molekul yang menandakan adanya senyawa metil ester. Pecahan dengan $\mathrm{m} / \mathrm{z}=199$ berasal dari $\mathrm{C}_{12} \mathrm{H}_{23} \mathrm{O}_{2}{ }^{+}$yang dihasilkan dari lepasnya radikal propil. Puncak dengan $\mathrm{m} / \mathrm{z}=87,101,115,129,143,157,171,185$ dan 199 merupakan pola fragmentasi deret ion $\mathrm{C}_{n} \mathrm{H}_{2 n-1} \mathrm{O}_{2}{ }^{+}$. Pola seperti ini merupakan pola karakteristik untuk senyawa-senyawa golongan ester rantai panjang (Creswel et al. 1982). Deret ion dengan rumus $\mathrm{C}_{n} \mathrm{H}_{2 n+1}{ }^{+}$mempunyai kelimpahan lebih sedikit pada $\mathrm{m} / \mathrm{z}=57,71$ dan 85 . Sedangkan deret ion $\mathrm{C}_{\mathrm{n}} \mathrm{H}_{2 \mathrm{n}-1^{+}}$dengan $\mathrm{m} / \mathrm{z}=55$ limpahannya sedikit lebih banyak. Hal ini membuktikan bahwa senyawa tersebut adalah metil miristat.

Puncak kromatogram dengan waktu retensi 23,115 menit dengan kemurnian 6,60\% merupakan senyawa metil palmitat.

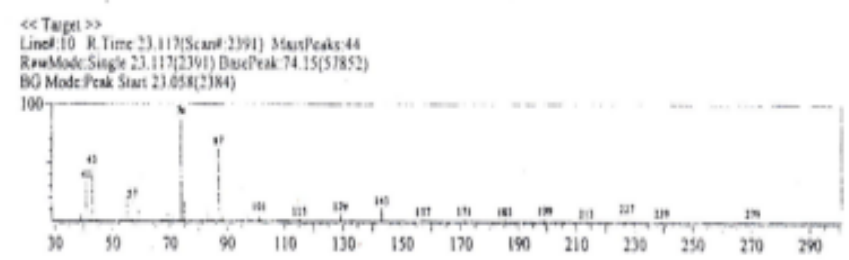

Gambar 5. Spektrum massa senyawa dengan waktu retensi 23,115 menit

Ion molekuler $\left[\mathrm{M}^{+}\right]=270$, puncak dasar muncul pada $\mathrm{m} / \mathrm{z}=74$ yang merupakan pemecahan $\beta$ melalui penataan ulang Mc. Lafferty. Deret ion dengan rumus $\mathrm{C}_{n} \mathrm{H}_{2 n+1} 1^{+}$muncul dengan kelimpahan kecil pada $\mathrm{m} / \mathrm{z}=57,71$ dan 85 . Sedangkan deret ion $\mathrm{C}_{\mathrm{n}} \mathrm{H}_{2 \mathrm{n}-1^{+}}$muncul dengan kelimpahan kecil $\mathrm{m} / \mathrm{z}=$ 55,69 , dan 83. Pemecahan yang paling banyak muncul dari deret ion $\mathrm{C}_{n} \mathrm{H}_{2 n-1} \mathrm{O}_{2}{ }^{+}$untuk ester alifatik 
yaitu $\mathrm{m} / \mathrm{z}=239$ berasal dari $\mathrm{C}_{16} \mathrm{H}_{31} \mathrm{O}^{+}$yang dihasilkan dari lepasnya gugus metoksi dari puncak ion molekul. Dari pola fragmentasinya dapat diketahui kalau senyawa tersebut adalah metil palmitat.

Puncak kromatogram dengan waktu retensi 24,946 menit dengan kemurnian 4,81\% merupakan senyawa metil oleat.

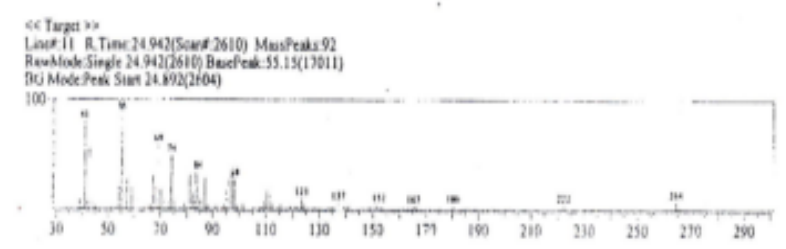

Gambar 6. Spektrum massa senyawa dengan waktu tR 24,942 menit

Puncak dasar muncul pada $\mathrm{m} / \mathrm{z}=55$ berasal dari $\mathrm{C}_{4} \mathrm{H}_{7}+$. Puncak pada $\mathrm{m} / \mathrm{z}=265$ berasal dari $\mathrm{C}_{18} \mathrm{H}_{33} \mathrm{O}^{+}$yang dihasilkan oleh lepasnya gugus metoksi dari puncak ion molekul. Fragmen dengan $\mathrm{m} / \mathrm{z}=222$ berasal dari lepasnya gugus $\mathrm{C}_{3} \mathrm{H}_{7}$. Fragmen dengan $\mathrm{m} / \mathrm{z}=180$ berasal dari pelapasan gugus $\mathrm{C}_{3} \mathrm{H}_{6}$ dari fragmen dengan $\mathrm{m} / \mathrm{z}=222$. Fragmen dengan $\mathrm{m} / \mathrm{z}=152$ berasal dari pelepasan gugus $\mathrm{C} \equiv \mathrm{O}^{+}$dari fragmen $\mathrm{m} / \mathrm{z} 180$. Fragmen dengan $\mathrm{m} / \mathrm{z}=96$ berasal dari pelepasan gugus $\mathrm{C}_{4} \mathrm{H}_{8}$ dari fragmen dengan $\mathrm{m} / \mathrm{z} 152$. Fragmen dengan $\mathrm{m} / \mathrm{z}=96$ mengalami panataan ulang Mc. Lafferty, melepaskan $\mathrm{C}_{3} \mathrm{H}_{5}$ menghasilkan fragmen dengan $\mathrm{m} / \mathrm{z}=55$ yang merupakan puncak dasar. Fragmen dengan $\mathrm{m} / \mathrm{z}=41$ berasal dari lepasnya gugus $\mathrm{CH}_{2}$ dari puncak dasar. Dari spektrum massanya dapat kita lihat kalau puncak ion molekulnya lebih kuat muncul pada $\mathrm{m} / \mathrm{z}=264$, namun pola fragmentasinya justru menghasilkan senyawa-senyawa yang tidak stabil. Hal ini disebabkan karena adanya senyawa nonlipida terlarut yang terdapat dalam sampel tersebut. Dari pola fragmentasinya dapat kita ketahui kalau senyawa tersebut adalah metil oleat.

\section{Minyak Kelapa tradisional}

Hasil analisis dengan menggunakan GC terdapat 8 puncak kromatogram yang menunjukkan bahwa terdapat 8 senyawa dan setelah dilakukan pendekatan pustaka terhadapa spektrum massa dari masing-masing puncak, didapat 5 jenis senyawa yang teridentifikasi, yaitu metil laurat, metil miristat, metil palmitat, metil oleat, dan metil stearat.

Puncak kromatogram dengan waktu retensi 18,362 menit dengan kemurnian 44,83 \% adalah senyawa metil laurat.

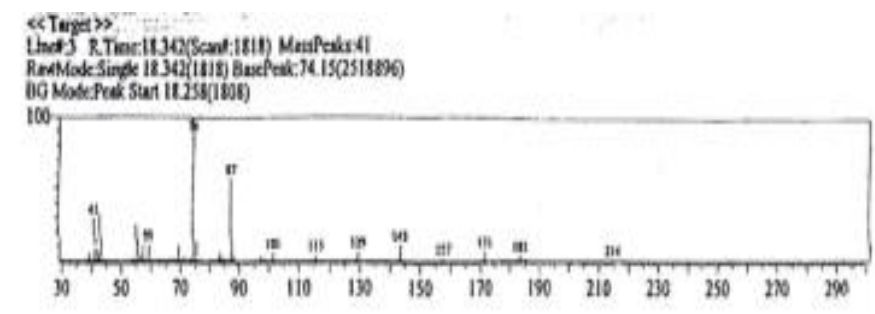

Gambar 7. Spektrum masa senyawa dengan waktu retensi 18,362 menit

Spektrum massa maupun pola fragmentasinya sama dengan metil laurat pada minyak kelapa fermentasi. Namun pada minyak kelapa tradisional ion molekul muncul sempurna $(\mathrm{m} / \mathrm{z}=214)$ 
Puncak kromatogram dengan waktu retensi 20,864 menit dengan kemurnian 22,83\% adalah senyawa metil miristat. Puncak kromatogram dengan waktu retensi 23,118 dengan kemurnian $12,82 \%$ adalah senyawa metil palmitat. Puncak kromatogram dengan waktu retensi 24,949 menit dengan kemurnian $11,68 \%$ adalah metil oleat. Spektrum massa dan pola fragmentasi ketiga senyawa ini sama seperti senyawa sejenis dari minyak kelapa fermentasi.

Puncak kromatogram dengan waktu retensi 25,158 menit dengan kemurnian 3,90\% adalah senyawa metil stearat.

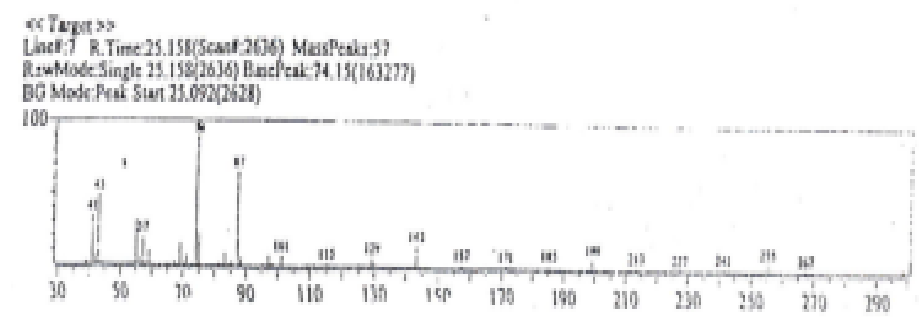

Gambar 8. Spektrum masa senyawa dengan waktu retensi 25,158 menit

Terlihat puncak dasar muncul pada $\mathrm{m} / \mathrm{z}=74$ yang berasal dari $\mathrm{C}_{3} \mathrm{H}_{6} \mathrm{O}_{2}{ }^{+}$yang terbentuk karena pemecahan $\beta$ melalui pemecahan Mc. Lafferty. Puncak pada $\mathrm{m} / \mathrm{z}=267$ berasal dari $\mathrm{C}_{19} \mathrm{H}_{32} \mathrm{O}^{+}$yang dihasilkan dari lepasnya gugus metoksi dari puncak ion molekul. Metil stearat yang stabil memiliki $\mathrm{m} / \mathrm{z}=298$, sementara pada data MS di atas $\mathrm{m} / \mathrm{z}=267$. Tidak munculnya puncak ion molekuler yang sebenarnya dikarenakan adanya senyawa non lipida terlarut yang berasal dari sampel itu (Silverstein et al. 1991) dan juga mungkin saja senyawa tersebut telah rusak saat pemanasan untuk menghilangkan pelarut. Selanjutnya pecahan dengan $\mathrm{m} / \mathrm{z}=255$ disebabkan oleh lepasnya radikal propil. Sementara pecahan dengan $\mathrm{m} / \mathrm{z}=87,101,115,129,143,157,171,185,199,213,227$, dan 241 dihasilkan dari lepasnya gugus $\mathrm{CH}_{2}$. Pola fragmentasinya membuktikan bahwa senyawa tersebut adalah benar metil stearat.

Dari hasil analisis dapat kita lihat adanya perbedaan kandungan asam lemak yang terdapat pada minyak kelapa fermentasi dan minyak kelapa tradisional.

Tabel 2. Hasil analisis kandungan asam lemak pada minyak kelapa fermentasi dan minyak kelapa tradisional.

\begin{tabular}{|l|l|l|l|}
\hline \multirow{2}{*}{ Asam lemak } & \multicolumn{2}{|l|}{ Kandungan asam lemak (\%) } & Keterangan \\
\cline { 2 - 3 } & M. Fermentasi & M. Tradisional & \\
\hline Asam laurat $\left(\mathrm{C}_{13}\right)$ & 39,13 & 44,83 & Asam lemak jenuh \\
Asam miristat $\left(\mathrm{C}_{15}\right)$ & 13,78 & 22,83 & Asam lemak jenuh \\
Asam palmitat $\left(\mathrm{C}_{17}\right)$ & 6,60 & 12,82 & Asam lemak jenuh \\
Asam oleat $\left(\mathrm{C}_{19}\right)$ & 4,81 & 11,68 & Asam lemak tak jenuh \\
Asam stearat $\left(\mathrm{C}_{19}\right)$ & - & 3,90 & Asam lemak jenuh \\
\hline
\end{tabular}

Semestinya kandungan asam lemak pada kedua jenis minyak kelapa ini relatif sama karena keduanya berasal dari satu pohon kelapa. Namun karena proses yang dikenakan kepada mereka berbeda, hasilnyapun berbeda. Baik jumlah minyak, bau, warna, maupun jenis dan komposisi asam lemaknya.

Pada tabel 2 dapat dilihat bahwa asam lemak pada minyak kelapa fermentasi dan minyak kelapa tradisional berbeda tidak hanya dalam jumlah tapi juga dalam jenis. Minyak kelapa tradisional mengandung 5 jenis asam lemak yaitu asam laurat, asam miristat, asam palmitat, asam oleat, dan 
asam stearat.Sedangkan minyak kelapa fermentasi hanya mengandung 4 jenis asam lemak yaitu asam laurat, asam miristat, dan asam palmitat dan asam oleat. Asam stearat tidak terdapat pada minyak kelapa fermentasi. Keberadaan asam sterat dalam minyak kelapa sangat sedikit $(2,5 \%)$ sehingga kemungkinan yang menyebabkan asam stearat yang jumlahnya sedikit ini tidak terdapat dalam minyak kelapa fermentasi karena telah habis dikonsumsi khamir. Tabel di atas juga menunjukkan bahwa asam laurat merupakan asam lemak jenuh yang memiliki kandungan tertinggi pada kedua jenis minyak kelapa ini. Hal ini sesuai dengan penelitian Sinclair (1993) dan Salunkhe et al (1992) bahwa minyak kelapa biasa disebut juga minyak laurat karena asam lemak jenis ini merupakan asam lemak terbanyak yang terkandung dalam minyak kelapa.

Selain itu, Tabel 2 juga menunjukkan bahwa jumlah asam lemak tak jenuh (asam oleat) pada minyak kelapa tradisional lebih banyak $(11,68 \%)$ dari minyak kelapa fermentasi $(4,81 \%)$. Padahal dalam proses pembuatan minyak kelapa tradisional pemanasan dilakukan lebih lama, sedangkan minyak kelapa fermentasi dilakukan dengan pemanasan yang rendah. Logikanya, kandungan asam lemak dengan ikatan rangkap dalam minyak kelapa fermentasi lebih banyak karena kurangnya pemanasan. Sedangkan minyak kelapa tradisional dengan pemanasan yang lebih lama justru kandungan asam lemak tak jenuhnya tinggi.

Sementara itu pada Tabel 2 dapat dilihat juga bahwa bukan hanya asam oleat dan asam stearat dalam minyak kelapa tradisional yang lebih tinggi prosentasinya dibandingkan dengan minyak kelapa fermentasi, tetapi semua jenis asam lemak yang terdapat dalam minyak kelapa lebih tinggi prosentasinya dalam minyak kelapa yang dibuat secara tradisional. Hal ini disebabkan oleh tiga hal. Pertama, jumlah asam lemak dalam minyak kelapa fermentasi lebih sedikit karena dikonsumsi khamir. Kedua, ada mikroorganisme lain yang juga mengkonsumsi asam lemak untuk menghasilkan energi.

Seperti yang telah kita ketahui bahwa lemak memegang peranan yang sangat penting dalam menghasilkan energi pada mahluk hidup. Senyawa ini mengandung energi tertinggi di antara relatif utama (> $9 \mathrm{kkal} / \mathrm{gr}$ ) dan disimpan dalam sel sebagai butir-butir lemak yang relatif murni serta dapat disimpan dalam jumlah besar pada jaringan adipose. Kira-kira energi relatif yang tersedia dari lemak terletak pada ketiga komponen asam lemaknya. Energi akan dihasilkan jika asam lemak ini dioksidasi menjadi karbondioksida dan air (Lehninger, 2004). Khamir juga berpeluang untuk mendapatkan energi dengan cara ini, disamping energi yang diperoleh dari proses fermentasi. Karena khamir juga memiliki mitokondria yang merupakan tempat oksidasi asam lemak. Khamir adalah organisme fakultatif yaitu organisme yang dapat hidup baik secara aerobik maupun anaerobik.

Kehadiran mikroorganisme lain juga mempengaruhi komposisi asam lemak dari minyak kelapa fermentasi. Kalau lingkungan fermentasi dimasuki oleh mikroorganisme lain, hasil dari proses ini akan berkurang atau bisa saja yang terbentuk adalah senyawa lain yang merupakan hasil metabolisme mikroorganisme pengganggu tersebut. Hal ini dapat dibuktikan dengan adanya peak-peak pada kromatogram yang tidak dapat dideteksi oleh MS. Selain itu, mikroorganisme ini kemungkinan besar mengoksidasi asam lemak untuk menghasilkan energi. Hal-hal inilah yang menyebabkan jumlah asam lemak pada minyak kelapa fermentasi lebih sedikit dari yang seharusnya. Sementara itu, pada pembuatan minyak kelapa tradisional prosesnya berlangsung sekaligus. Santan kelapa diuapkan sampai seluruh airnya menguap, protein terdenaturasi menjadi tahi minyak (glendo) kemudian diperoleh minyak. Semua proses itu dibantu dengan pemanasan.

Ketiga, kemungkinan panas yang dipakai dalam pembuatan minyak kelapa tradisional belum cukup untuk memutuskan atau merusak ikatan rangkap. Menurut Ketaren (1986), minyak kelapa dan minyak kelapa sawit disamping mengandung asam lemak tak jenuh juga mengandung asam lemak jenuh, sehingga relatif stabil dan tidak mudah rusak oleh panas. 


\section{KESIMPULAN}

Berdasarkan hasil penelitian dan pembahasan, dapat ditarik beberapa kesimpulan yaitu:

1. Jumlah asam stearat pada minyak kelapa sedikit sehingga tidak terdapat asam stearat pada minyak kelapa fermentasi disebabkan karena habis dikonsumsi khamir.

2. Dari segi jumlah dan jenis asam lemak, minyak kelapa tradisional lebih baik. Namun dari segi fisik minyak kelapa fermentasi lebih baik dalam hal jumlah minyak, waktu pemanasan dan tampilan.

3. Proses pembuatan mempengaruhi jumlah dan jenis asam lemak

\section{DAFTAR PUSTAKA}

Almatsier, S. 2002. Prinsip dasar ilmu gizi. Gramedia Pustaka utama:

Buckle, K. A., Edwars, G. H., Fleet, M., Wooton. 1987. Ilmu pangan. Terjemahan dari food science. Oleh Hari Purnomo dan Adiyono, UI-Press: Jakarta

Creswell, C.F., Runguisht, A.O., dan Campell, M.M. 1982. Analisis spektrum senyawa organik. ITB: Bandung

Fardianz, S. 1989. Mikrobiologi pangan. ITB : Bandung

Fessenden \& Fessenden. 1989. Kimia organik. Jilid I. Edisi ketiga. Terjemahan dari organic chemistry. Oleh Aloysius H. P. Erlangga: Jakarta.

Hard, H. 2004. Kimia Organik. Edisi keenam. Terjemahan dari Organik Chemistry. Oleh S. Achmadi. Erlangga: Jakarta.

Ketaren, S. 1986. Minyak dan lemak pangan. UI-Press: Jakarta.

Lehninger, L.A.1987. Dasar-dasar biokimia. Jilid II. Terjemahan dari principles of biotechnology. Oleh M. Thenawidjaja. Erlangga: Jakarta.

Marx, J. L. 1991. Revolusi biokimia. Jilid II. Terjemahan dari A Revolution of biotechnology. Oleh W, Yatim. Yayasan obor: Jakarta.

Murray, R.K.D.K. Grammer, P.A. Mayer, \& V.W. Rodwell. 2003. Biokimia Harper. Terjemahan dari Harper's Biochemistry. Oleh Kartono. EGC: Jakarta

Page, D.S. 1997. Prinsip-prinsip biokimia. Edisi I. Terjemahan dari principles of Biological Chemistry. Oleh R. Soendoro. Erlangga: Jakarta

Pine, S., Hendrikson, J.B., Cram, D.J., Hammond, G.S. 1980. Kimia organik. Jilid II. Edisi keempat. Terjemahan dari Organic Chemistry, oleh Roehyati \& Sasanti. Institut Teknologi Bandung: Bandung

Poetjiadi, A. 1994. Dasar-dasar biokimia. Ul-Press: Jakarta

Pudjaatmaka, A.H. 2002. Kamus kimia. Balai Pustaka: Jakarta

Rahman, A. 1999. Teknologi fermentasi Industrial. Jilid II. Arcan: Jakarta

Silverstein, R.M., Blasser, G.C., and Morril, T.C. 1991. Spektrometric identification of organic compounds. $5^{\text {th }}$ edition. Jhon willey and Sons: USA

Sudarmadji, S. 1984. Prosedur analisa untuk bahan makanan dan pertanian. Liberty: Yogyakarta

Winarno, F.G. 1999. Minyak goreng dalam menu masyarakat. Gramedia pustaka utama: Jakarta

Winarno, F.G. \& Fardianz. 1993. Biofermentasi dan biosintesa protein. Angkasa: Bandung. 